\title{
WMA calls for urgent support to fight Ebola
}

$\mathrm{V}$ ery few countries are offering the level of resources needed to fight the Ebola outbreak in West Africa, Prof. Vivienne Nathanson of the British Medical Association told the World Medical Association (WMA) assembly in Durban, South Africa, on Oct. 8. "We should be saying something to force our countries to recognize that this is a global problem," she said, before a debate on an emergency motion urging greater support to combat the epidemic. "Otherwise, we are going to see deaths that rise into the hundreds of thousands or even millions," said the BMA's director of Professional Activities.

The WMA motion passed unanimously. It includes a call for "enhanced support" to combat the epidemic, plus the necessary supplies of personal protective equipment, adequate training in infection control, more public communication and strengthening of infection control in countries "not yet affected." It urges all WMA member nations to "contact their national government" about these measures.

The motion did not include everything WMA representatives wanted. The Junior Doctors' Network, a WMA branch representing doctors with less than 10 years in practice, wanted to include a clause stating that medical residents in Ebola-affected countries are in dire need of supervision and protective equipment. Dr. Patrick Ezie, a family medicine resident at the University of Abuja Teaching Hospital in Abuja,
Nigeria, and the network leader for Africa, told CMAJ that Ebola has been devastating for junior doctors, who are nearly always the first physicians to see patients in West African hospitals.

When Ebola hit Nigeria in July and August, residents at his hospital bought used personal protective suits on the black market for as much as 50000 Nigerian Naira (Can\$338) in case they were asked to see a patient suspected of having the virus; the suits are only supposed to be used once. And in Freetown, Sierra Leone, medical residents are mourning the loss of a resident who died from Ebola in October. The WMA agreed to take up the junior doctors' issue in the future, but did not include it in the motion, because other frontline

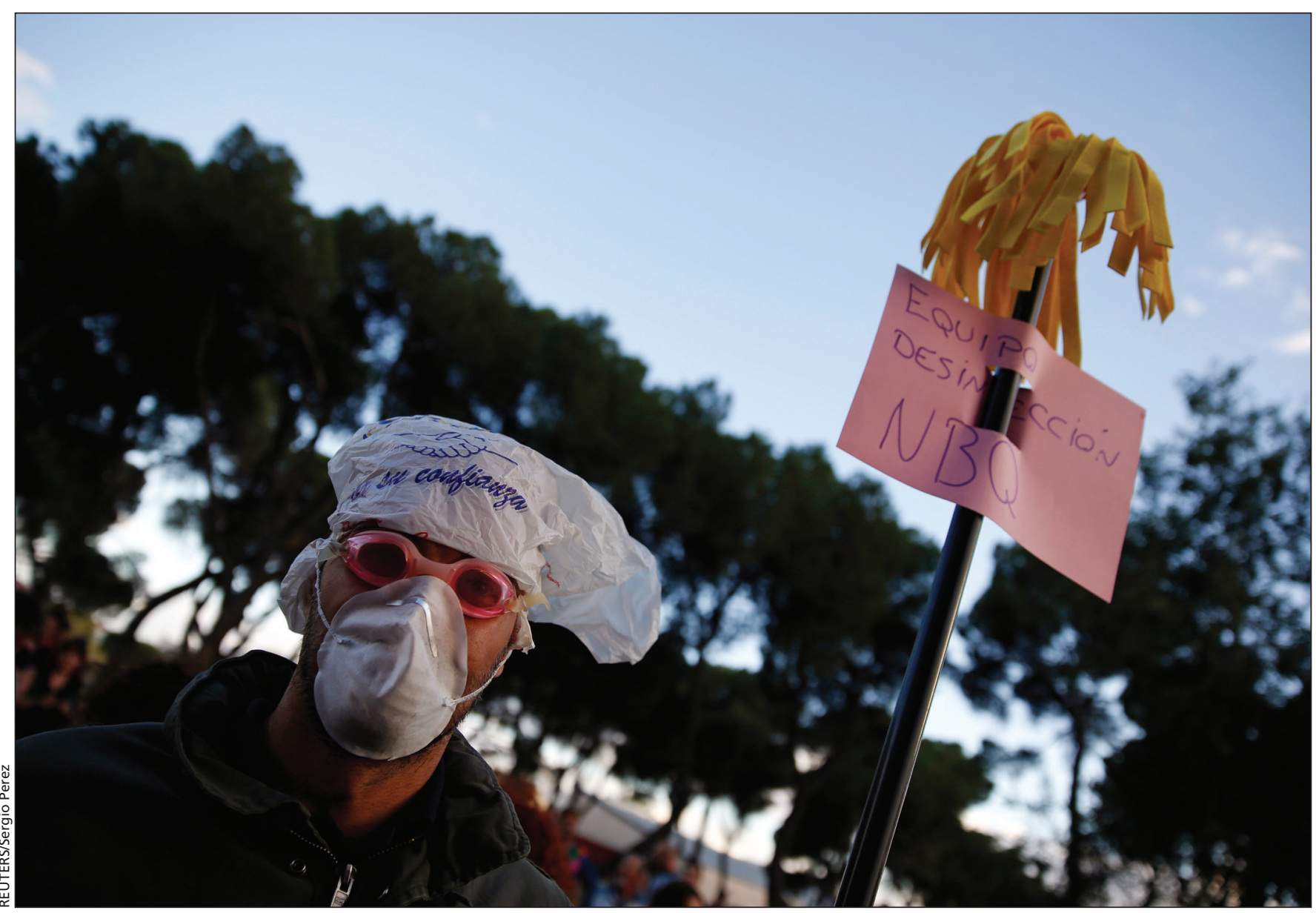

A protestor in Madrid, Spain, demands an investigation into how nurse Teresa Romero contracted Ebola. Cases of patients with the virus are now in Europe and the United States. 
workers are also at high risk and lack necessary resources.

But the news that physicians on the front lines in West Africa say "they are totally ignored by international agencies," as Ugandan physician Margaret Mungherera told the assembly, did prompt additional words: the emergency motion recommends that national governments and aid agencies "work with health care providers on the ground."

For Mungherera, who stepped down as WMA president in October, the Ebola outbreak is close to home. Uganda has faced several Ebola outbreaks since 2000 and is now coping with Marburg virus, a related hemorrhagic fever virus. It recently claimed the life of a 30-year-old radiology technologist in Kampala; 99 people who may have had contact with him are in quarantine.

Ebola is hitting closer to home for Europeans and North Americans too, with a handful of recent cases in the United States, France, Germany and Spain.

But cases of Ebola in the global North pale compared to West Africa, where more than 8000 people have contracted the disease and over 3850 have died of it, according to the latest report from the US Centers for Disease Control and Prevention.

"We need to communicate loudly, now," said Dr. André Bernard, an anesthesiologist from Halifax, Nova Scotia who helped draft the emergency motion. Canada has committed tens of millions of dollars along with a mobile lab and supplies, including 128000 face masks that the Public Health Agency of Canada shipped in October.

But the United Nations said in September that the amount needed to fight the virus approaches US $\$ 1$ billion. Dr. Jim Yong Kim, the global health physician at the helm of the World Bank, said he will ask the governments of highincome countries this week to support a US $\$ 20$ billion fund for global health emergencies. - Miriam Shuchman MD, Durban, South Africa

CMAJ 2014. DOI:10.1503/cmaj.109-4919 